\title{
A Contribution to the Histological Study of the Alveoli of the Human Lung
}

By

\author{
Kazuyo, Shimai and Kiyoharu, Tamaru \\ (From the Department of Anatomy, School of Medicine, Keio Gijuku \\ University. Director: Prof. T. Taniguchi).
}

\section{Introduction}

Magendie (1840) stated that some parts of the walls of the alveolar blood capillaris are exposed to the air in the alveolar spaces. The great majority of investigators, however, accepted generally the view of Kölliker (1880-1881) and others, that the alveolar wall of the human lung is composed of the socalled " respiratory epithelium" i. e. the non-nucleated plaques and the nucleated small cuboidal cells. After Kölliker's report, there has been disagreement of opinion among histologists, regarding the presence of the non-nucleated plaques. Oppel (1905) denied strongly the presence of the non-nucleated plaques. This question remanins to be answered.

Recently Seemann (1931), Loosli (1935) and Clara (1936) held that the presence of alveolar epithelium is discontinuous, that isolated cells without any processus or groups of these cells are seen within the mesh of alveolar capillaries, and that the capillaries are denuded everywhere. In Japan, Akazaki (1942), Hozaka (1942), Baba (1947) and Shimai (1950) agree with these authors.

In this paper, Shimai and Tamaru describe the results of the observations upon the structure of the pulmonary alveolar walls of human adults, particularly about the nature of the walls of the alveolar blood capillaries.

\section{Material and Methods}

The materials used for our study were five human lungs of apparently normal, healthy adults. The tissues were fixed as quickly as possible after death in a 10 per cent formalin solution and formalin- 
alcohol mixture, and some of the formalin-fixed specimens were later fixed with Levi's solution, imbedded into paraffin, and sectioned in the thickness of three to five microns. The slides were divided into two groups; one group being those oxidized with periodic acid, and the other being those without any treatment. Both groups were stained by ordinary hematoxylin-eosin stain, van Gieson's technique, Azan-stain, Mallory's elastin stain, Bielschowsky-Maresch's silver impregnation technique and Brom-silver method. Among these staining procedures, Weigert's method, van Gieson's method, and Heidenhain's iron hematoxylin method demonstrated the fibres most beautifully.

\section{Observations}

The extremely expanded alveolar walls of human adult lungs form a very thin layer. Numerous alveolar septd devide alveolar spaces. In general, the ends of the alveolar septa are thickened, more than the other parts of the alveolar walls or alveolar septa, and contain more interstitial connective tissue elements and fairly large quantities of smooth muscle fibres. As Ogawa (1920) certified, this shows the presence of the isolated circular muscle fibres. Studies on the muscle fibres, elastic fibres; reticular fibres, and collagenous fibres of the alveolar walls have been reported by Orsós (1907), Ogaw a (1920) and Balt isberger (1921).

The blood capillaries on the alveolar walls are highly developed, giving an impression in thin sections. That the greater part of the alveolar wall is occupied by capillaries. Nucleated cuboidal cells cover the capillary walls discontinuously.

Our slides; stained by hematoxylin-eosin procedure, Azan stain (Fig. 1), Mallory's technique and Heidenhain's iron hematoxylin stain (Fig. 2), show that the bordering of cells is distinct, and that the cuboidal cells are situated along the walls of capillaries singly or in groups consequently, the denuded surfaces are exposed to the alveoolàr spaces.

The cuboidal cell possesses clear cytoplasm, a large round nucleus with scarce chromatin and one or two distinct nucleoli. The processus like structure of the cuboidal cell is not visible even in the adequately stained hematoxylin-eosin preparation after the periodic acid oxidation. Concluding from our precise observation the presence of the nonnucleated plaques as structural entities is definitely denied. We know well the cuboidal cells on the concave region of the winding alveolar 
blood capillaries are called "Nischen Zellen" by Seemann (1931).

Now we shall discuss whether the walls of the alveolar capillaries are exposed directly to the alveolar cavites or not. As generally accepted, the wall of the blood capillaries are composed of endothelial cells, reticular fibres (so-called "Grundhäutchen") and pericytes, but in the pulmonery capillaries the presence of pericytes is denied.

Seemann (1931) and Bergmann (1935) reported that the reticular fibres of the capillary walls are derived from the branches of the reticular fibres on the alveolar walls, forming very fine networks on the walls of the blood capillaries. We also recognized the very fine fibres, originating from the thick reticular fibres of the interstitial connective tissue, running into the walls of blood capillaries. In thin sections impregnated by Bielschowsky-Maresch's procedure or the brom-silver method, where the capillaries are cut in cross section, the fibres run abruptly on the capillary walls, indicating their netlike structure (Fig. 3). A s generally accepted, the highly abundant development of the elastic fibres within the alveolar walls was clearly seen. In our tissue section, particularly in those stained by Weiger.t's stain after the oxidation with periodic acid, disrupted thick elastic fibres ran within the connective tissue along the capillary walls or embracing the cuboidal cells. Branching from these thick elastic fibres were finer fibres which ran into the walls of the naked blood capillaries. This continous relationship was clearly seen particularly in the specimens stained by Weigert's technique after the periodic acid treatment (Fig. 4).

On the denuded capillary walls; it is ascertained that these elastic fibres are the constituent of the network. As the result of the observation of our specimens oxidized with periodic acid and stained by van Gieson's procedure, we could not affirm the intrusion of collagenous fibres into the walls of the denuded blood capillaries. The stainability of the fibres with acid fuchsin could not distinguished from the reticular fibres, which belong to the same category. (Fig. 5). According to Seemann (1931), the reticular fibres of the capillary walls are considered as the continuation of the "paracapillar collagenous fibres" of Hering.

We could not find any muscle fibres within the walls of the naked blood capillaries, but could recognize the existence of few muscle, fibres on some parts of alveolar walls and of alveolar, septa. .

From these results, we conclude that the walls of the apparently denuded blood capillaries are covered not. only by the reticular mesh 
but also by the net; of the extremely fine elastic fibres and, further, that the collagenous fibres branching from those of the interstitial connective tissue may possibly intrude into them.

According to Policard (1935), fibres of all natures form network on the alveolar walls and are imbedded within the hyaline ground substance. Our results show that the naked capillary walls, which are exposed to the alveolar spaces, are also covered by fine network of these fibres and are imbedded within the hyaline groundsubstance. The membranous protrusion of the cuboidal cells covering the denuded capillary walls could not be confirmed.

\section{Summary}

(1) The situation of the epithelial cells on the alveolar walls are discontinuous.

(2) The non-nucleated plaques are not demonstrated.

(3) The walls of the denuded alveolar blood capillaries are covered by the network composed of reticular and elastic fibres and probably of collagenous fibres.

\section{References}

KöHiker., 1881. Zur Kenntnis des Baues der Lunge des Menschen. Verhandls der physik-medizin. Geseilsch. zur Würzburg Neue Folge. Bd. 16.

Orsós, 1907. Über das elastis:he Gerüst der normalen und der emphysamatösen Lunge. Beitr. zur pathol. Anat. Bd. 41.

Og a w a, C., 1920. Contribution to the histology of the respiratory spaces of the vertebrate lungs. Amer. Journ. of Anat. Vol. 27.

Baltisberger, W., 1921. Über die Muskulatur der menschlichen Lunge. Zeitschr. f. Anat. u. Entwickl. Bd. 61.

Seemann, G., 1931. Histobiologie der Lungenalveole, Jena.

Clara, M., 1936. Vergleichende Histologie des Nierenglomerulus und der Lungenalveole nach Untersuchung beim Menschen und beim Kaninchen. Zeitschr. f. mikr.-anat. Forsch. Bd. 40.

Magendie., Lara, M, Policard, A, Refer to W. Bargmann, 1936. Handb. d. mikr. Anat. d. Menschen V/2 Die Lungenalveole. Berlin.

Loosli, C. G., 1935. The rabbit's lung after phrenicotomy and pneumothorax. Anat. Rec. Vol. 62.

K. Akazaki and T. Hozaka., 1942. On the lining of the epithelial cells on the alveolar wall of the human lung. Medicine and Biology. Vol. 2 No. 2 (Japanese).

T. Hozaka., 1942. The contribution of the histogenetic studies of the alveolar epithelial cells of the lung. Hokuetsu-Igaku-Kaishi. 57th Year. No. 12 (Japanese).

T. Baba., 1947. The contribution of the morphological and histogenetic studies of the alveolar epithelial cells (so-called, respiratory epithelium). Anatomical study of the twin foetus. No. 8 (Japanese). 


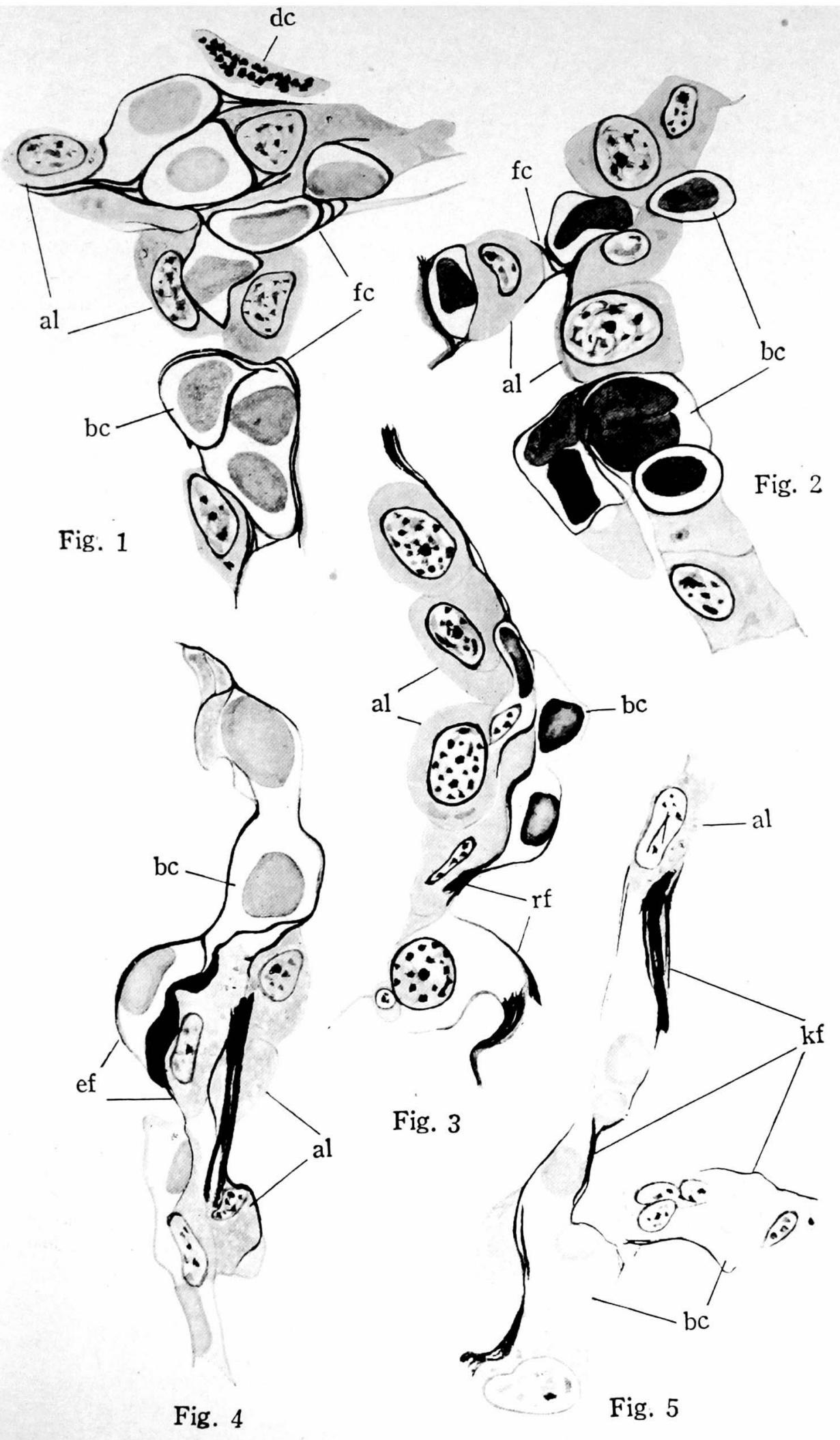


Maximow, A, A. and W. Bloom. 1948. Textbook of Histology. 5th. ed., Chap. 22. The respiratory system, Philadelphia.

K Shimai., 1951. The histogenetic studies of the alveolar epithelium. Keio, Igaku. Vol. 28 No. 6 (Japanese).

\section{Explantation of Figures}

All figures were drawed with the Abbe camera lucida on the height of the stage and with the Zeiss apochromatic immersion objectives, 90 , n. a. 1.3, ocular 20.

Fig. 1. Azan stain (after oxidation with periodic acid).

Fig. 2. Heidenhains iron-hematoxylin stain.

Fig. 3. Bielschowsky-Maresch's silver impregnation techniques.

Fig. 4. Weigert's method (after oxidation with periodic acid).

Fig. 5. van Gieson's method (after oxidation with periodic acid).

$\mathrm{fc}=$ fibres of connective tissues, $\mathrm{rf}=$ reticular fibres, ef $=$ elastic fibres, $\mathbf{k f}=$

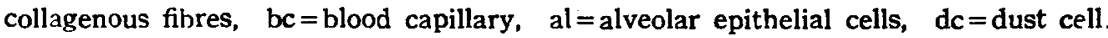

